\title{
Fatty acid composition and antioxidant capacity of pomegranate seed oil
}

\author{
Taner Bozkurt $1{ }^{*}$ and Zeynep Ergun ${ }^{2}$ \\ ${ }^{1}$ Bozkurt Biotechnology, R\&D Services Industry and Trade Limited Company, Adana, Turkey. \\ ${ }^{2}$ Adana Alparslan Turkes Science and Technology University, Faculty of Engineering, Department of Bioengineering, \\ Adana, Turkey.
}

GSC Biological and Pharmaceutical Sciences, 2021, 15(02), 103-110

Publication history: Received on 06 April 2021; revised on 10 May 2021; accepted on 13 May 2021

Article DOI: https://doi.org/10.30574/gscbps.2021.15.2.0126

\begin{abstract}
Pomegranate (Punica granatum) is a perennial herb with its long history and has been the symbol of health, fertility and spirituality. In addition to being consumed as fresh fruit, pomegranate is consumed as pomegranate juice, syrup, pomegranate syrup and many different product groups. In particular, pomegranate seeds, which are often produced as waste, are evaluated separately in terms of their fatty acid composition and antioxidant capacity. In this study, the fatty acid composition of pomegranate seed oils was determined by gas chromatography/mass spectrophotometry (GC/MS). Total antioxidant activity analysis was performed using DPPH (2, 2-diphenyl-1-picrylhydrazyl) method and antioxidant activity value was determined as trolox equivalent (TE). In the study, it was determined that the antioxidant capacity was $171.44 \mathrm{mg}$ TE / 100g. According to GC / MS analysis, it was determined that the most dominant fatty acid was punicic Acid (68.12\%). Oleic acid (8.51\%), linoleic acid (6.71\%) and palmitic acid (5.55\%) are the highest fatty acids after punicic acid. It is clear that apart from the widespread consumption of pomegranate fruit, which is very beneficial for health, its seeds can also be used.
\end{abstract}

Keywords: Punica granatum; Pomegranate; Punicic acid; Fatty acid; Seed oil; Antioxidant capacity

\section{Introduction}

The belief in the healing effects of plants extends from the existence of humanity to the present day. The healing effects of plants are closely related to their active components, and their effectiveness varies from plant species to growing conditions. Among these plants, pomegranate has been used as a medicinal fruit due to its anti-cancer, immunosuppressive activities, antioxidant, antimicrobial, anti-inflammatory, and its use is increasing day by day [1, 2, $3,4]$.

The current scientific appellation of the pomegranate, Punica granatum, is originated from Pomum (apple) granatus (granular) or seeded apple [5]. It is native to Asia and is a deciduous shrub or small tree. It has been utilized in oriental traditional medicine for a long time [6, 7, and 8]. Pomegranate has been accepted as a manifestation of life, longevity, health, splendor, abundance, awareness, morality and spirituality $[9,10]$. Since ancient times, it has been accepted as a "healing food" because it has many beneficial effects on many diseases [1].

Pomegranate is commonly grown in Spain, Azerbaijan, China, Afghanistan, Turkey, USA, Armenia, India, Iran, Uzbekistan, the Middle East, Pakistan, Tunisia, and Israel, dry regions of Southeast Asia, Peninsular Malaysia, the East Indies and tropical Africa [11]. It is reported in different sources that the cultivated pomegranate production area is 3 hundred thousand hectares and the production is 3 million tons. Approximately $76 \%$ of this production takes place in India, Iran, China, Turkey and the United States [11, 12, and 13]. Among the substantial pomegranate produces, Turkey

\footnotetext{
${ }^{*}$ Corresponding author: Taner Bozkurt

Bozkurt Biotechnology R\&D Services Industry and Trade Limited Company, Adana, Turkey.
} 
produced 559.171 tons and 537.847 tons in 2019 and 2018, respectively [14]. And as can be seen in Figure 1 the production level has been rising.

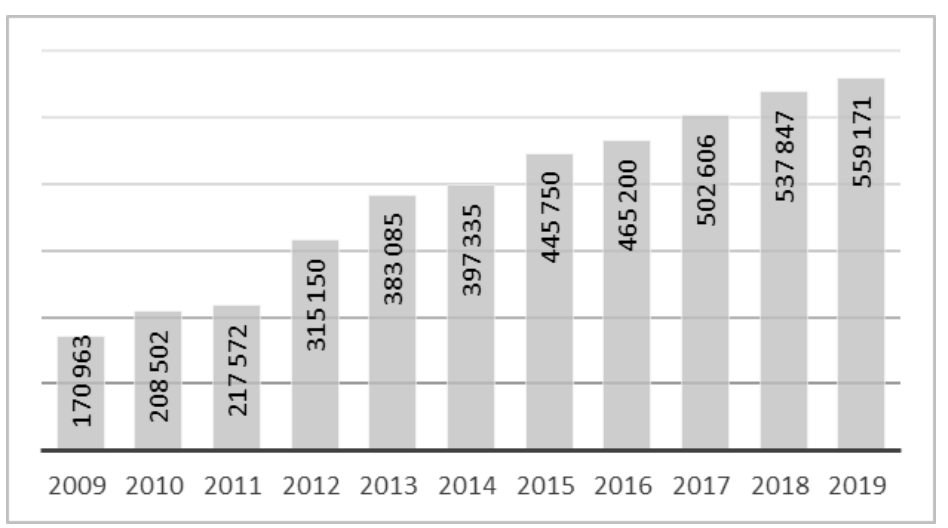

Figure 1 Pomegranate Production of Turkey over Years (tons) [14].

In addition to being fresh-consumed fruit, pomegranate has also been used for different purposes such as a source of healing [15, 16, and 17]. The Pomegranate plant consists of various parts such as fruit skin, leaves, flowers, seeds, arils, fruit juice, roots and bark $[18,19]$. The internal structure of the pomegranate fruit, which has a spherical shape, is irregular and consists of many tightly arranged grains, generally ranging from white to dark red. Each pomegranate seed consists of a seed surrounded by juice. In addition to being a fresh-consumed fruit, pomegranates are fruits valued for their decorative appearance, consumed and marketed as fruit juice, syrup (pomegranate syrup), teas, extracted grains, seed oils and other products. As a healing source, pomegranate juice contains relatively more minerals such as iron and elements such as calcium, selenium, chlorine, cobalt, chromium, cesium, copper, potassium, magnesium, manganese, molybdenum, sodium, rubidium and zinc. Recently, pomegranate consumption has been reported to have health benefits that have shown efficacy against a variety of diseases, including partially atherosclerosis, coronary heart disease, and prostate cancer, and infectious diseases, hypertension. Approximately $100 \mathrm{~g}$ edible pomegranate contains 68-72 kcal energy, 0.95-1.0 g protein, 6.1-7 mg vitamin C, 1-3 mg sodium, $3 \mathrm{mg}$ calcium, 16.6-17.17 g carbohydrate, 0.3$0.7 \mathrm{mg}$ iron, $3 \mathrm{mg}$ magnesium, $0.07 \mathrm{mg}$ copper, $259379 \mathrm{mg}$ Potassium, $0.3 \mathrm{mg}$ niacin and many more nutrients [18, 20, $21,22,23,24]$.

Pomegranate seeds, leaves and peels have many beneficial phytochemicals such as sterols, lignins and terpenoids. There are alkaloids in bark, root bark and leaves; simple galloyl derivatives in leaves; triglycerides and fatty acids in seed oils and seeds; organic acids, anthocyanins and phenolic acids in fruit juice; simple galloyl derivatives in leaves [25, 26, 27, $28]$. There are flavonols in rind [29, 30], fruit [31,32], bark and leaves [31,33]. In addition, pomegranate peel, leaf, and fruit peel are rich in ellagitannins and gallotannins $[34,35,36]$. The presence of anthocyanidins and anthocyanins, catechins and procyanidins in peel and juice has been reported $[33,37,38]$. The presence of estrogens in juice, seeds and shell extracts [39] and essential oils in seeds has been reported [5, 40]. Dried pomegranate seeds include the steroid estrogen estrone [41] and [42], isoflavone phytoestrogens such as genistein and daidzein, and the phytoestrogen kumestrol $[43,44]$. It is known that pomegranate seeds constitute approximately $20 \%$ of the whole fruit by weight and are an important source of antioxidants. It has been suggested that among the beneficial effects of pomegranate seeds can prevent DNA damage, reduce the risk of cancer, and also alleviate menopausal symptoms $[18,45,46,47]$.

Punicic acid, the conjugated isomer, is the predominant fatty acid in pomegranate seed oil. This fatty acid, which is a long-chain omega-5 polyunsaturated fatty acid, is a conjugated isomer of linolenic acid like pomegranate seeds, Momordica charantia, Trichosanthes bracteata, Trichosanthes kirilowii, and Trichosanthes cucumerina seed oils are among the sources of punicic acid $[48,49]$. It is known that punicic acid has antioxidant and antitumor properties. It is known to inhibit the growth of skin cancer, prostate cancer, colon cancer and similar types of cancer [50,51,52]. Lansky et al. [53] reported that pomegranate oil as a whole, and punicic acid in particular, causes the invasion (inhibits) of human prostate cancer cells.

Within the scope of this study, it was aimed to determine the fatty acid composition and antioxidant capacity of pomegranate seed, whose rich content was investigated by many studies. The determination of fatty acids belonging to pomegranate seeds rich in bioactive compounds and used in many fields from health to cosmetics will shed light on future studies 


\section{Material and methods}

\subsection{Material}

Pomegranate seeds used in this study were obtained from local companies and kept at room temperature until analysis.

\subsection{Method}

\subsubsection{Fatty Acid Analysis}

Oil extraction of the pomegranate seeds we preserved was made with $n$-hexane. Analysis of fatty acids was made according to the method of IUPAC IID19 [54]. Gas chromatography (GC; Perkin Elmer, Shelton, USA) was used to determine the fatty acid composition. Flame ionization detector (FID) and column $(30 \mathrm{~m} \times 0.25 \mathrm{~mm}$ ID, $0.25-\mu \mathrm{m}$ film thickness) were used for chromatographic separation. The oven temperature was kept for 10 min by increasing to 220 ${ }^{\circ} \mathrm{C}$ by $120^{\circ} \mathrm{C}(2 \mathrm{~min})$ and $5^{\circ} \mathrm{C} / \mathrm{min}$; Injector and detector temperatures were set to $280^{\circ} \mathrm{C}$ and $260^{\circ} \mathrm{C}$, respectively. Results were calculated in \% with mean deviations.

\subsubsection{Determination of DPPH radical scavenging capacity}

Free radical scavenging activity was analyzed by the 2, 2-diphenyl-1-picrylhydrazyl (DPPH) assay [55, 56]. 100 $\mu \mathrm{l}$ of methanolic sample was homogeneously mixed with fresh $2.9 \mathrm{ml}$ DPPH solution (in $0.1 \mathrm{mM}$ methanol). The mixture was kept at room temperature for 30 minutes in the dark. The mixtures were read using a spectrophotometer at $517 \mathrm{~nm}$ absorbance. The trial was run in 3 replicates and the values obtained were determined as Trolox equivalent (TE) corresponding to $100 \mathrm{~g}$ sample.

\subsubsection{Statistical analysis}

Fatty acid analyzes were carried out in three replicates according to a random trial design. Variance analysis was performed with the SAS-JMP statistical program (SAS Institute Inc., Cary, NC). The means were compared with the least significant difference (LSD) at $\mathrm{P}<0.05$.

\section{Results and discussion}

In this study analysis of total oil amount, fatty acid composition and total antioxidant activity in Punica granatum seeds were made. According to the results, the total amount of fat was determined as $1.44 \mathrm{~g} / 100 \mathrm{~g}$. As a result of GC analysis, the major compound in the fatty acid composition was determined as Punicic Acid (68.12\%). This fatty acid was followed by oleic acid (8.51\%), linoleic acid (6.71\%) and palmitic acid (5.55\%), respectively (Table 1).

Total antioxidant capacity was determined as $171.44 \mathrm{mg}$ TE/100g. Punicic acid, which is determined as the major compound, is a long chain polyunsaturated omega- 5 fatty acid and it has been emphasized by many researchers that it is the main component of pomegranate fatty acids. In one of these studies, Melo (2012) reported that punicic acid is the dominant fatty acid [3]. Similarly, the amount of punicic acid was found to be 78.3-83.4\% by Pande and Akoh [57], 70$76 \%$ by Kýralan et al. [58], 62.43-73\% by Elshaarawy \& Nahapetian [59].

Fadavi et al. [60] examined the fatty acid content of the seeds of 25 different pomegranate varieties in Iran. In the study, it was found that punicic acid was the most dominant fatty acid with $31.8-86.6 \%$ and it was found to be linoleic acid (0.7-24.4\%), oleic acid (0.4-17.4\%), stearic acid (0.3-9.9\%), palmitic acid (3.7-16.7\%) and arachidic acid (0-3.9\%) followed. Similarly, all these fatty acids have been identified in our study. Lauric and arachidic acid, which the researchers stated that they could not be detected, were detected in our study, and the presence of lignoceric acid was not detected in our study. It is predicted that these similarities and differences may arise from differences between types and locations. In a different study not mentioning lauric acid and arachidic acid, Hernandez et al. [61] found that in 3 different pomegranate varieties have punicic acid (66.76-79.29\%) followed by linoleic (4.98-7.74\%), oleic (4.70$5.91 \%)$, stearic (\% 1.6-2.38) and palmitic (2.99-3.83\%) acid. It is noteworthy that only 5 fatty acids were mentioned in the study. 
Table 1 Fatty acid composition of Punica granatum Seed (Figures in parentheses are angular transformation values of percentage of response)

\begin{tabular}{|l|l|l|}
\hline & Fatty acid & Percentage (\%) \\
\hline 1 & Punicic Acid C18:3 & $68.12^{\mathrm{a}}(55.68)$ \\
\hline 2 & Palmitic Acid (C16: 0) & $5.55^{\mathrm{cd}}(13.62)$ \\
\hline 3 & Palmitoleic Acid (C16: 1) & $0.07^{\mathrm{h}}(1.53)$ \\
\hline 4 & Stearic Acid (C18: 0) & $3.86^{\mathrm{e}}(11.34)$ \\
\hline 5 & Oleic Acid (C18: 1n9c) & $8,51^{\mathrm{b}}(16.96)$ \\
\hline 6 & Linoleic Acid (C18: 2n6c) & $6,71^{\mathrm{c}}(15.01)$ \\
\hline 7 & Arachidic Acid (C20: 0) & $0.83^{\mathrm{f}}(5.23)$ \\
\hline 8 & Eicosenoic Acid (C20: 1n9c) & $0.95^{\mathrm{f}}(5.59)$ \\
\hline 9 & Behenic Acid (C22: 0) & $0.35^{\mathrm{g}}(3.39)$ \\
\hline 10 & Caproic Acid (C6: 0) & $0.05^{\mathrm{h}}(1.28)$ \\
\hline 11 & Tricosanoic Acid (C23:0) & $0.06^{\mathrm{h}}(1.34)$ \\
\hline 12 & Lauric Acid (C12:0) & $0.02^{\mathrm{h}}(0.88)$ \\
\hline 13 & Myristic Acid (C14: 0) & $0.05^{\mathrm{h}}(1.29)$ \\
\hline 14 & Heptadecanoic Acid (C17: 0) & $0,03^{\mathrm{h}}(1.00)$ \\
\hline 15 & Others & $4.82^{\mathrm{de}}(12.68)$ \\
\hline
\end{tabular}

LSD: $1,61^{* * *}, \mathrm{P}<0.05^{*}, \mathrm{P}<0.01^{* *}, \mathrm{P}<0.001^{* * *}$, The LSD value was calculated according to the angle transformation value. Different letters (a-h) indicate significant differences by the LSD test $(\mathrm{p} \leq 0.05)$.

Siano et al. [62] compared the physicochemical and biochemical features of the oils of pomegranate (Punica granatum), sweet cherry (Prunus avim) and pumpkin (Cucurbita maxima) seeds. While cherry and pumpkin seed oils contain high amounts of linoleic acid, pomegranate seed oil has been found to contain polyunsaturated fatty acids and monounsaturated fatty acids with eicosapentaenoic acid. They also found catalpic acid, Eptadecanoic acid and trace amounts of nervoic acid in pomegranate seed oil. Differently, while these fatty acids were not detected in our study, fatty acids such as Myristic, Heptadecanoic, Behenic Acid were determined in our study, unlike this study. In addition, researchers have suggested that pomegranate, cherry and pumpkin seed oils can be used as both protective and functional components in food, medicine and cosmetics, and can contribute to the prevention of diseases. In addition, they emphasized that these oils have the potential to create a natural filter against radiation in pharmaceutical, food and cosmetic products because they provide UV light absorption. They found that especially pomegranate and pumpkin seed oils have high absorption in UV-A and UV-B.

Fernandes et al. [63] analized the fatty acid and vitamin E compositions of nine pomegranate varieties grown in Spain. It was determined that the total fat content varied between $4.44-13.70 \%$ and the most prevailing fatty acid in all cultivars was punicic acid (77.3-83.6\%). This was followed by linoleic acid with 3.9-5.4\% and oleic acid with 3.1-5.7\%, respectively. Differently, in this study, while punicic acid was detected in a lower concentration, linoleic Acid (6.71\%) and oleic acid (8.51\%) were detected in higher amounts.

Studying the fatty acids of seed oils of 21 different pomegranate varieties, Elfalleh et al. [64] stated that qualitatively, there are no significant differences between varieties in terms of fatty acid composition. Quantitatively, they determined that the dominant fatty acid was linolenic acid (main isomer is punicic acid) (44.51-86.14\%). In addition, researchers found oleic acid (3.03-12.88\%), linoleic acid (3.57-13.92\%), stearic acid (1.68-15.64\%), palmitic acid (3.13-11.82\%), lignoceric acid $(<2.53 \%)$, gadoleic acid $(0.50-4.91 \%)$, arachidic acid $(<1.70 \%)$ and myristic acid $(<0.85 \%)$.

Thitipramote et al. [65] investigated the bioactive compounds, protoanthocyanin contents and their antioxidant activities of pomegranate peel and seed in their study. They obtained the highest bioactive content results from acetone extractions. Antioxidant activities differed, and according to DPPH, better results were obtained from seed extracts (0.034-0.512 mg TE/g) from shell extracts (2069-2957 mg TE/g) and the highest results were obtained in extractions 
with acetone. Differently, higher antioxidant capacity (171.44 mg TE/100g) was determined in this study, and it is predicted that this may be based on many other reasons from location differences to harvest season.

Guo et al. [66] found that pomegranate fruit had the highest total value in their study on the antioxidant activities of the peel, seed and flesh parts of 28 different fruits. It is noteworthy that pomegranate peels in particular have a very high antioxidant activity.

\section{Conclusion}

Pomegranate fruit, which has a long history, has very important chemical components for human health. In this study, oil was obtained from the seeds of the pomegranate plant. As a result of the analysis of the fatty acid composition, it was determined that the dominant fatty acid was punicic acid (68.12\%). Additionally, the presence of oleic acid, linoleic acid, palmitic acid and stearic acid was also detected. This study has also proven that pomegranate seeds, which are mostly produced as a result of fruit processing, have important fatty acids. It is clear that pomegranate seeds can be included more in human diets due to their rich content.

\section{Compliance with ethical standards}

\section{Acknowledgments}

The authors would like to thank all researchers who cited this study.

\section{Disclosure of conflict of interest}

The authors declare that there are no conflict of interest.

\section{References}

[1] Viuda-Martos M, Fernández-López J, Pérez-Álvarez JA. Pomegranate and its many functional components as related to human health: a review. Comprehensive Reviews in Food Science and Food Safety. 2010; 9(6): 635654.

[2] Miguel MG, Neves MA, Antunes MD. Pomegranate (Punica granatum L.): A medicinal plant with myriad biological properties-A short review. Journal of Medicinal Plants Research. 2010; 4(25): 2836-2847.

[3] Carvalho Filho JM. Pomegranate seed oil (Punica granatum L.): a source of punicic acid (conjugated $\alpha$-linolenic acid). J Human Nutri Food Sci. 2014; 2(1): 1-11.

[4] Medjakovic S, Jungbauer A. Pomegranate: a fruit that ameliorates metabolic syndrome. Food \& function. 2013; 4(1): 19-39.

[5] Da Silva JAT, Rana TS, Narzary D, Verma N, Meshram, DT, Ranade SA. Pomegranate biology and biotechnology: a review. Scientia Horticulturae. 2013; 160: 85-107.

[6] Das AK, Mandal SC, Banerjee SK, Sinha S, Das J, Saha BP, Pal M: Studies on antidiarrheal activity of Punica granatum seed extract in rats. Journal of Ethnopharmacology. 1999; 68: 205-208.

[7] Jafri MA, Aslam M, Javed K, Singh S. Effect of Punica granatum Linn. (flowers) on blood glucose level in normal and alloxan induced diabetic rats. Journal of Ethnopharmacology. 2000; 70: 309-314.

[8] Arun N, Singh DP. Punica granatum: a review on pharmacological and therapeutic properties. International journal of pharmaceutical sciences and research. 2012; 3(5): 1240.

[9] Mahdihassan S. Outline of the beginnings of alchemy and its antecedents. The American journal of Chinese medicine. 1984; 12(01n04): 32-42.

[10] Prakash CVS, Prakash I. Bioactive chemical constituents from pomegranate (Punica granatum) juice, seed and peel-a review. Int J Res Chem Environ. 2011; 1(1): 1-18.

[11] Sharma J, Ramchandra KK, Sharma D, Meshram DT, Ashis Maity NN. Pomegranate Cultivation Marketing and Utilization. 2014. 
[12] Melgarejo P, Calín-Sánchez Á, Carbonell-Barrachina ÁA, Martínez-Nicolás JJ, Legua P, Martínez R, Hernández F. Antioxidant activity, volatile composition and sensory profile of four new very-early apricots (Prunus armeniaca L.). Journal of the Science of Food and Agriculture. 2014; 94(1): 85-94.

[13] Kushwaha SC, Bera MB, Kumar P. Pomegranate. In Antioxidants in Fruits: Properties and Health Benefits. Springer, Singapore. 2020; 295-316.

[14] Turkish Statistical Institute (TUIK); $2021 \quad$ [cited $2021 \quad$ May 1$]$ Available from https://data.tuik.gov.tr/Kategori/GetKategori?p=tarim-111\&dil=1

[15] Durgaç C, Özgen M, Simsek Ö, Kaçar YA, Kiyga Y, Çelebi S, ... \& Serçe S. Molecular and pomological diversity among pomegranate (Punica granatum L.) cultivars in Eastern Mediterranean region of Turkey. African Journal of Biotechnology. 2018; 7(9).

[16] Şimşek Ö, Dönmez D, İmrak B, Özgüven AI, Kaçar YA. Narda (Punica granatum L.) Yeni Nesil Dizileme Teknolojisi Kullanılarak SSR Markırlarının Geliștirilmesi. Uluslararası Tarım ve Yaban Hayatı Bilimleri Dergisi. 2018; 4(2): 161-167.

[17] Poyrazoğlu E, Gökmen V, Artık N. Organic acids and phenolic compounds in pomegranates (Punica granatum L.) grown in Turkey. Journal of food composition and analysis. 2002; 15(5): 567-575.

[18] Lansky EP, Newman RA. Punica granatum (pomegranate) and its potential for prevention and treatment of inflammation and cancer. Journal of ethnopharmacology. 2007; 109(2): 177-206.

[19] Hassani Moghaddam E, Sepahvand A. Medicinal Properties of Pomegranate. Herbal Medicines Journal. 2019; 4(3): 127-139.

[20] Holland D, Hatib K, and Bar-Ya'akov I. Pomegranate: Botany, horticulture, breeding. Hort. Rev. 2009; 35: 127191.

[21] Dhinesh Kumar V, Ramasamy D. Pomegranate Processing and Value Addition: A Review. Indian Horticulture Journal. 2016; 6(1): 1-12.

[22] Heber D, Schulman RN, Seeram NP, editors. Pomegranates: ancient roots to modern medicine. CRC press; 2006 Jul 7.

[23] Wetzstein HY, Zhang Z, Ravid N, Wetzstein ME. Characterization of Attributes Related to Fruit Size in Pomegranate. Hortscience. 2011; 46(6): 908-912.

[24] Waheed S, Siddique N, Rahman A, Zaidi J, Ahmad S. INAA for dietary assessment of essential and other trace elements in fourteen fruits harvested and consumed in Pakistan. Journal of Radioanalytical and Nuclear Chemistry. 2004; 260(3): 523-531.

[25] Newman RA, Lansky EP, Block ML. Pomegranate: The Most Medicinal Fruit, 1st Edn. Basic Health Publication, Laguna Beach, CA. 2007; 1-120.

[26] Akkawi M, Abu-Lafi S, Abu-Remeleh Q. Phytochemical screening of Pomegranate juice, peels, leaves and membranes water extracts and their effect on $\beta$-hematin formation, a comparative study. Pharm. Pharmacol. Int. J. 2019; 7: 193-200.

[27] Artik N, Cemeroglu B, Murakami H, Mori T. Determination of phenolic compounds in pomegranate juice by HPLC. Fruit Process. 1998; 8: 492-499.

[28] Miguel G, Dandlen S, Antunes D, Neves A, Martins D. The effect of two methods of pomegranate (Punica granatum L) juice extraction on quality during storage at 4 C. Journal of Biomedicine and Biotechnology. 2004; (5): 332.

[29] Kim ND, Kaplan B, Gupta M, Amichay A, Lansky E, Livney T, Neeman I, Poirier D, Luu-The V, Nicholls P, Kirby A, Jiang WG, Mansel R, Mehta R, Gewirtz D. Chemopreventive and adjuvant therapeutic potential of pomegranate (Punica granatum) for human breast cancer. Breast Cancer Res. Treat. 2002; 71: 203-217.

[30] Sinha K, Saha PD, Datta S. Response surface optimization and artificial neural network modeling of microwave assisted natural dye extraction from pomegranate rind. Industrial crops and products. 2012; 37(1): 408-414.

[31] Ramezanian A, Erkan M. Pomegranates (Punica granatum L.). Fruit and Vegetable Phytochemicals: Chemistry and Human Health, 2nd Edition. 2017; 1179-1194.

[32] Mirdehghan SH., Rahemi M. Seasonal changes of mineral nutrients and phenolics in pomegranate (Punica granatum L.) fruit. Scientia Horticulturae. 2007; 111(2): 120-127. 
[33] Rahimi HR, Arastoo M, Ostad SN. A comprehensive review of Punica granatum (pomegranate) properties in toxicological, pharmacological, cellular and molecular biology researches. Iranian journal of pharmaceutical research: IJPR. 2012; 11(2): 385.

[34] Gil MI, Tomás-Barberán FA, Hess-Pierce B, Holcroft DM, Kader AA. Antioxidant activity of pomegranate juice and its relationship with phenolic composition and processing. Journal of Agricultural and Food chemistry. 2000; 48(10): 4581-4589.

[35] Nawwar MA, Hussein SA, Merfort I. Leaf phenolics of Punica granatum. Phytochemistry. 1994; 37(4): 1175-1177.

[36] Mayer W, Görner A, Andrä K. Punicalagin und Punicalin, zwei Gerbstoffe aus den Schalen der Granatäpfel. Justus Liebigs Annalen der Chemie. 1977; 11-12.

[37] Hernandez F, Melgarejo P, Tomas-Barberan, FA, Artes F. Evolution of juice anthocyanins during ripening of new selected pomegranate (Punica granatum) clones. European Food Research and Technology. 1999; 210(1): 39-42.

[38] Jaiswal V, DerMarderosian, A., Porter JR. Anthocyanins and polyphenol oxidase from dried arils of pomegranate (Punica granatum L.). Food Chemistry. 2010; 118(1): 11-16.

[39] Kho YL, Jung W, Kwon D, Kim JH. Identification of estrone in pomegranate (Punica granatum) extracts by liquid chromatography-tandem mass spectrometry. Food Science and Biotechnology. 2010; 19(3): 809-813.

[40] Abbasi H, Rezaei K, Rashidi L. Extraction of essential oils from the seeds of pomegranate using organic solvents and supercritical C02. Journal of the American Oil Chemists' Society. 2008; 85(1): 83-89.

[41] Heftaman E, Bennett ST. Identification of estrone in pomegranate seeds. Phytochemistry. 1996; 5: 1337-9.

[42] Moneam MA, El-Sharasky AS, Badreldin MM. Oestrogen content of pomegranate seeds. J. Chromatogr. 1988; 43842.

[43] Hossin FLA. Effect of pomegranate (Punica granatum) peels and it's extract on obese hypercholesterolemic rats. Pak J Nutr. 2009; 8(8): 1251-7.

[44] Sharaf A, Nigm SAR. The oestrogenic activity of pomegranate seed oil. J. Endocrinol. 1964; 29: 91-2.

[45] Guo S, Deng Q, Xiao J, Xie B, Sun Z. Evaluation of antioxidant activity and preventing DNA damage effect of pomegranate extracts by chemiluminescence method. Journal of agricultural and food chemistry. 2007; 55(8): 3134-3140.

[46] Tehranifar A, Zarei M, Nemati Z, Esfandiyari B, Vazifeshenas MR. Investigation of physico-chemical properties and antioxidant activity of twenty Iranian pomegranate (Punica granatum L.) cultivars. Scientia Horticulturae. $2010 ; 126(2): 180-185$.

[47] Jing PU, Ye T, Shi H, Sheng Y, Slavin M, Gao B, Yu LL. Antioxidant properties and phytochemical composition of China-grown pomegranate seeds. Food Chemistry. 2012; 132(3): 1457-1464.

[48] Khoddami A, Man YBC, Roberts TH. Physico-chemical properties and fatty acid profile of seed oils from pomegranate (Punica granatum L.) extracted by cold pressing. European journal of lipid science and technology. 2014; 116(5): 553-562.

[49] Khajebishak Y, Payahoo L, Alivand M, Alipour B. Punicic acid: A potential compound of pomegranate seed oil in Type 2 diabetes mellitus management. Journal of cellular physiology. 2019; 234(3): 2112-2120.

[50] Grossmann ME, Mizuno NK, Schuster T, Cleary MP. Punicic acid is an $\omega-5$ fatty acid capable of inhibiting breast cancer proliferation. International journal of oncology. 2010; 36(2): 421-426.

[51] Aruna P, Venkataramanamma D, Singh AK, Singh RP. Health benefits of punicic acid: a review. Comprehensive Reviews in Food Science and Food Safety. 2016; 15(1): 16-27.

[52] Liu W, Zhao Q, Lv L, Yan S, Song Q, Chen T, Yao Q. Pomegranate seed oil enhances the percutaneous absorption of trans-resveratrol. Journal of oleo science, ess17144. 2018; 64(4): 479-487.

[53] Lansky EP, Harrison G, Froom P, Jiang WG. Pomegranate (Punica granatum) pure chemicals show possible synergistic inhibition of human PC-3 prostate cancer cell invasion across Matrigel $^{\mathrm{TM}}$. Investigational new drugs. 2005; 23(2): 121-122.

[54] IUPAC. Standard methods for analysis of oils, fats and derivatives, 6th edn. (5th edn. Method II.D.19), Pergamon Press Oxford, Oxford. 1979. 
[55] Brand-Williams W, Cuvelier ME, Berset CLWT. Use of a free radical method to evaluate antioxidant activity. LWTFood science and Technology. 1995; 28(1): 25-30.

[56] Chinnici F, Bendini A, Gaiani A, Riponi C. Radical scavenging activities of peels and pulps from cv. Golden Delicious apples as related to their phenolic composition. Journal of Agricultural and Food Chemistry. 2004; 52(15): 46844689.

[57] Pande G, Akoh CC. Antioxidant capacity and lipid characterization of six Georgia-grown pomegranate cultivars. Journal of agricultural and food chemistry. 2009; 57(20): 9427-9436.

[58] Kýralan M, Gölükcü M, Tokgöz H. Oil and conjugated linolenic acid contents of seeds from important pomegranate cultivars (Punica granatum L.) grown in Turkey. Journal of the American Oil Chemists' Society. 2009; 86(10): 985-990.

[59] El-Shaarawy MI, Nahapetian A. Studies on pomegranate seed oil. Fette, Seifen, Anstrichmittel. 1983; 85(3): 123126.

[60] Fadavi A, Barzegar M, Azizi MH. Determination of Fatty Acids and Total Lipid Content in Oilseed of 25 Pomegranates Varieties Grown in Iran. Journal of Food Composition and Analysis. 2006; 19(6-7): 676-680.

[61] Hernandez F, Melgarejo P, Olias JM, Artes F. Fatty acid composition and total lipid content of seed oil from three commercial pomegranate cultivars. Production, Processing and Marketing of Pomegranate in the Mediterranean Region: Advances in Research and Technology. 2000; 205-209.

[62] Siano F, Straccia MC, Paolucci M, Fasulo G, Boscaino F, Volpe MG. Physico-chemical properties and fatty acid composition of pomegranate, cherry and pumpkin seed oils. Journal of the Science of Food and Agriculture. 2016; 96(5): 1730-1735.

[63] Fernandes L, Pereira JA, Lopéz-Cortés I, Salazar DM, Ramalhosa E, Casal S. Lipid composition of seed oils of different pomegranate (Punica granatum L.) cultivars from Spain. International Journal of Food Studies. 2015; $4(1)$.

[64] Elfalleh W, Ying M, Nasri N, Sheng-Hua H, Guasmi F, Ferchichi A. Fatty acids from Tunisian and Chinese pomegranate (Punica granatum L.) seeds. International journal of food sciences and nutrition. 2011; 62(3): 200206.

[65] Thitipramote N, Maisakun T, Chomchuen C, Pradmeeteekul P, Nimkamnerd J, Vongnititorn P, Pintathong P. Bioactive compounds and antioxidant activities from pomegranate peel and seed extracts. Food and Applied Bioscience Journal. 2019; 7(3): 152-161.

[66] Guo C, Yang J, Wei J, Li Y, Xu J, Jiang Y. Antioxidant activities of peel, pulp and seed fractions of common fruits as determined by FRAP assay. Nutrition research. 2003; 23(12): 1719-1726. 